\title{
Özofagus alkali yanıklarında antienflamatuar ajanların etkisi: Deneysel çalışma
}

\author{
Anti-inflammatory agents' effect on esophageal alkali burn: An experimental study
}

\author{
Semih Koçyiğit ${ }^{1}$, Fatma Koçyiğit ${ }^{2}$, Serpil Bayındır ${ }^{2}$
}

\section{ÖZET}

Amaç: Korozif özofagus yanıkları (KÖY) hastalarda striktür oranının \%50'nin üzerine çıktığını gösteren çalışmalar mevcuttur. Çalışmamızda rat özofagus alkali yanık modelinde antienflamatuar ajanların etkisini araştırmayı amaçladık.

Yöntemler: Çalışmada vücut ağırlıkları 220-250 gr arasında değişen Wistar Albino türü 28 adet rat kullanıldı. Bütün gruplara korozif özofajitine benzer şekilde KÖY oluşturuldu. Rat'lar 12 saat aç bırakılarak kas içi ketamin HCL $(90 \mathrm{mg} / \mathrm{kg})$ ve xylazine $(10 \mathrm{mg} / \mathrm{kg})$ ile genel anestezi sağlandı. Her grupta 7 rat olacak şekilde 4 gruba ayrıldı. Grup l' deki rat'ların $1 \mathrm{~cm}$ özofagus segmenti lümen içi $1 \mathrm{ml}$ serum fizyolojik ile yıkandı. Grup II rat'lara KÖY oluşturulduktan sonra parenteral antibiyotik verildi. Grup III rat'lara KÖY oluşturulduktan sonra antibiyotik ve deksametazon, grup IV rat'lara ise prednizolon ve antibiyotik tedavisi verildi. Rat'ların tümü 21. günde sakrifiye edilerek abdominal özofagusları histopatolojik inceleme için çıkarıldı. Submukoza kollajen artışı, muskularis mukoza hasarı ve tunika muskularis hasarı histopatolojik olarak belirlendi.

Bulgular: Yapılan inceleme ile Grup l' de hasar olmadığı görüldü. Grup I ile Grup II, III, IV karşılaştırıldığında Grup II, III ve IV' de her üç parametrede hasar saptandı. Grup II, Grup III ile karşılaştııılıı̆ında Grup III' de hasar daha az saptandı. Grup II, Grup IV ile karşılaştırıldığında muskularis mukoza ve tunika muskularis hasarı açısından istatistiksel olarak anlamlı farklılık saptandı $(p<0.05)$.

Sonuç: Sonuç olarak prednizolon muskularis mukozaya kadar ilerleyen yeni kollojen sentezini azaltabilir ancak darlık oluşumunu azaltıcı etkisi deksametazona göre farklı değildir.

Anahtar kelimeler: Deksametazon, kollojen, korozif özofagus yanığı, prednizolon.

\begin{abstract}
Objective: Corrosive burns of the esophagus are some reports demonstrating that the stricture ratio exceeds $50 \%$ in the case of a severe burn. In this experimental animal study of rats, we aimed to investigate the effects of the anti-inflammatory agents in esophageal alkali burns.
\end{abstract}

Methods: Twenty-eight Wistar albino rats, weighing from 220 to $250 \mathrm{gr}$, were used in the study. And following a starving period of 12 hours, we provided general anesthesia with intramuscular ketamin $\mathrm{HCL}(90 \mathrm{mg} / \mathrm{kg})$ and $x y-$ lazine $(10 \mathrm{mg} / \mathrm{kg})$. A corrosive burn just like the corrosive esophagitis was done under general anesthesia. The rats were divided into four groups ( 7 rats for each). The intraluminal area of $1 \mathrm{~cm}$ in the esophagus of the rats of the first group was washed using serum physiologic $(1 \mathrm{ml})$. Group II received parenteral antibiotic treatment. Group III received antibiotic and dexamethasone regiment, while the Group IV received antibiotic and prednisolone. Each animal was sacrificed on the $21^{\text {st }}$ day, and their abdominal esophagus was resected for histopathological investigation. The submucosal increase in the collagen, damage to the muscularis mucosa and to the tunica muscularis were three parameters demonstrating the injury histopathologically.

Results: There was no injury in the Group I. There was injury in each parameter in the Group II, III, and IV compared with Group I. In the comparison between Group II and III, there was less injury in the Group III. In comparison with Group II there was also significant injury in the muscularis mucosa and the tunica muscularis in the Group I $(p<0.05)$.

Conclusion: Prednisolone may decrease the new collagen synthesis that progresses up to muscularis mucosa, but the effect on the lowering the stricture formation is not better than dexamethasone.

Key words: Dexamethasone, collagen, corrosive burns of the esophagus, prednisolone

${ }^{1}$ Elazığ Ĕ̆itim Araştırma Hastanesi, Göğüs Cerrahisi Kliniği, Elazığ, Türkiye

${ }^{2}$ Elazı̆̆ Ĕ̆itim Araştırma Hastanesi, Anesteziyoloji ve Reanimasyon Kliniği, Elazı̆̆, Türkiye

Yazışma Adresi /Correspondence: Serpil Bayındır,

Elazığ Eğitim ve Araştrıma Hastanesi, Anesteziyoloji ve Reanimasyon Kliniği, Elazığ Email: serpilbayindir@gmail.com

Geliş Tarihi / Received: 03.06.2015, Kabul Tarihi / Accepted: 03.10.2015

Copyright @ Dicle Tıp Dergisi 2015, Her hakkı saklıdır / All rights reserved 


\section{GíRiş}

Korozif özofagus yanıklarından (KÖY) sonra özofagus striktürü gelişmesi ciddi bir problemdir. Teknolojinin gelişmesi ve 1900'lü yılların başında özofagoskopun keşfedilmesi ile KÖY'e bağlı striktürlerin önlenmesinde ve tedavisinde çok önemli adımlar atılmıştır $[1,2]$.

Geniş spektrumlu antibiyotiklerin 1950 yılından sonra kullanılmaya başlanması, parenteral beslenme, antegrad ve retrograd balon dilatasyonlar ve uygulamaya giren stent yöntemi ile KÖY'e bağl1 mortalite azalmıştır [1,3].

Korozif özofagus yanıkları, sülfirik asit ve hidroklorik asit gibi asitlerin ve çoğunlukla (\%7590) potasyum hidroksit $(\mathrm{KOH})$, sodyum hidroksit $(\mathrm{NaOH})$ ve sodyum hipokloriti gibi kuvvetli alkalilerin çocuklar tarafindan kazayla veya erişkinlerin intihar amacıyla içilmesi sonucu oluşur. Olguların \%80'ini 5 yaş altındaki çocuklar oluşturur [2,3]. Çocuklarda alkali madde içimi sonrası özofagus yanı̆̆1 oluşma oran $1 \% 24$ 'dür ve bunlarında \%1235 'inde striktür meydana gelmektedir. Ciddi yanığ 1 olan hastalarda striktür oranın \%50'nin üzerine çıktığını gösteren çalışmalar mevcuttur [4,5].

Korozif maddelerin özofagusta yaptıkları hasar, içilen maddenin tipine, konsantrasyon oranına, miktarına ve temas süresine bağlıdır. Korozif madde içimine bağlı özofagus yanıkları 3 grupta incelenir.

1. Derece yanıklar: Yüzeyel (mukozal) hiperemi ve ödem vardır.

2. Derece yanıklar: Yanık mukozayı aşmış ve tüm duvarı etkilemiştir. Mukoza yok olmuştur ve ülserasyon vardır.

3. Derece yanıklar: Yanık periözofageal dokuya ulaşmıştır, perforasyon ve mediastinit bulguları mevcuttur $[6,7]$.

Akut devrede (ilk 4 gün) özofagusta akut bir inflamasyon vardır. Yanığın derecesine göre inflamasyon tüm katları tutup perforasyona neden olabilir. Yanığın ikinci gününde submukozal kan damarlarındaki tromboz nekroza yol açabilir. Yanığ1 takip eden ilk 15 gün (subakut devre) sonuna doğru nekrotik dokular dökülür ve geride kalan ülserasyon sahalarında neovaskülarizasyon başlar. Sikatrizasyon devresi; 3-4. haftalarda başlar. Bu dönemde inflamasyonun yerini bağ dokusu alır. Mukoza ve submukozanın yerini fibröz bir doku almıștır. Mukozal reepitelizasyon 6 haftada tamamlanır [2].

Günümüzde tedavinin temelini oluşturan antibiyotik ve steroid tedavisinin kökeni deneysel hayvan çalışmalarına dayanmaktadır. Antibiyotik tedavisinin amacı zedelenen özofagusu bakteriyel invazyondan korumak, steroid kullanımının amacı ise yaranın gerileme gücünü, epitelizasyon hızını ve dolayısıyla yara kontraksiyonunu inhibe etmektir. Üçüncü derece yanıklarda bu tedavinin etkisiz olduğu bilinmektedir [3, 4, 6]. Kortikosteroidler karbonhidrat, protein ve lipit metabolizması üzerine etkilidirler. S1v1-elektrolit dengesini düzenlerler, en önemli etkileri immunsupresif ve antienflamatuar etkileridir. Prednizolon delta-1 hidrokortizondur. Deksametazon 9 alfa-fluoro-16 alfa-metilprednizolon'dur. Plazmadaki yarılanma ömrü üç saat kadardır. Plazma proteinlerine en az bağlanan glukokortikoiddir [8].

\section{YÖNTEMLER}

$\mathrm{Bu}$ çalışma Lokal Etik Kurul onayının alınmasını takiben üniversite deneysel araştırma merkezinde gerçekleştirildi. Çalışmada vücut ağırlıkları 220 250 gr arasında değişen Wistar Albino türü 28 adet rat kullanıldı ve Laboratuar Hayvanlarının Bakım ve Kullanımı Kılavuzuna (Guide for the Care and Use of Laboratory Animals) uygun olarak insanc1l bir muameleye tabi tutuldu. Rat'lar deney sonuna kadar yedişerli gruplar halinde kafeslerde tutuldular ve bakımlarında standart pellet yemi ve şehir içme suyu kullanıldı. Rat'lar sabit sicaklık ve rutubet altında korundular. Tüm rat'lar KÖY oluşturulmadan önce ve cerrahi öncesi 12 saat aç bırakıldı.

Her biri 7 rat'dan oluşan dört grup oluşturuldu.

Grup I (Kontrol grubu): Rat'ların 1cm.'lik özofagus segmenti lümen içi $1 \mathrm{ml}$ serum fizyolojik ile y1kand1 $(n=7)$.

Grup II (Alkali özofagus yanığı oluşturulan grup) : Bu gruptaki rat'ların özofagus lümeni içine 1 ml. \%50'lik NaOH verildi, 180 saniye beklendikten sonra $\mathrm{NaOH}$ geri alınarak 60 saniye süre ile özofagus lümeni distile su ile yıkandı. Alkali özofagus yanığı oluşturulan bu gruba paranteral antibiyotik (ampisilin $150 \mathrm{mg} / \mathrm{kg}$ gün) verildi $(\mathrm{n}=7)$.

Grup III (Alkali özefagus yanığı oluşturularak deksametazon verilen grup): $\mathrm{Bu}$ gruptaki rat'lara 
özofagus yanığını takiben deksametazon $(1 \mathrm{mg} / \mathrm{kg}$ gün) paranteral olarak verildi. İkinci grupta uygulanan antibiyotik rejimi bu grup içinde uygulandı $(n=7)$.

Grup IV (Alkali özefagus yanı̆̆ı oluşturularak prednizolon verilen grup): Bu gruptaki rat'lara özofagus yanığını takiben prednizolon ( $1 \mathrm{mg} / \mathrm{kg} /$ gün $)$ paranteral olarak verildi. İkinci grupta uygulanan antibiyotik rejimi bu gruba da uyguland $1(n=7)$.

$\mathrm{Bu}$ çalışmada Gehanno ve arkadaşlarının [9] tarif ettiği korozif özofajitine benzer şekilde KÖY oluşturuldu. Ratlar işlemden önce 12 saat aç b1rakıldı ve tüm rat'ların işlem öncesi tartısı alındı. Anestezi kas içi ketamin HCL (90 mg/kg) ve xylazine $(10 \mathrm{mg} / \mathrm{kg})$ ugulanması ile sağlandı. Rat'lar yatırılarak dört ekstremite bez flasterlerle tespit edildi. Karın cildi traşlandıktan sonra \%10 alkol-iyot ile temizlendi. Göbek üstü median laparatomi ile batına girildi. Abdominal özofagus çevresindeki bantlardan serbestleştirilerek izole edildi. 1,5 cm'lik distal özofagus proksimalinden geçici olarak 3/0 poliglaktin sütürle bağlandı. Distal özofagus distalinden yine geçici olarak 3/0 poliglaktin sütürle bağlandiktan sonra Grup I' deki rat'lara $1 \mathrm{ml}$ serum fizyolojik verildi. Grup II, III ve IV' deki rat'lara 1 $\mathrm{ml} \% 50 \mathrm{NaOH}$ verildi, 180 saniye beklendi ve KÖY oluşturuldu. Daha sonra $\mathrm{NaOH}$ geri alınarak 60 saniye süreyle distal özofagusları distile su ile yıkanarak distal özofagusun proksimal ve distalini kapatan düğümler açıldı. Batın tam kat olarak devamlı 3/0 ipek sütürle kapatıldı. Tüm rat'lar işlemden 3 saat sonra çeşme suyu ve pellet yemleri ile beslendi.

Tüm gruplara KÖY oluşturulduktan sonra parenteral antibiyotik (ampisilin $150 \mathrm{mg} / \mathrm{kg} / \mathrm{gün}$ ) verildi. Grup II rat'lara parenteral antibiyotik tedavisinden başka bir tedavi uygulanmadı. Grup III‘deki rat'lara KÖY oluşturulduktan sonra parenteral antibiyotik ve deksametazon ( $1 \mathrm{mg} / \mathrm{kg} / \mathrm{gün})$ verildi. Grup IV'deki rat'lara ise parenteral antibiyotik ve prednizolon ( $1 \mathrm{mg} / \mathrm{kg} /$ gün) verildi.

Histopatolojik değerlendirme yapılacak her gruptaki rat'ların $1,5 \mathrm{~cm}$ distal özofagus dokusu tamponlu nötral \%10'luk formalin içinde 24 saat tespit edilip parafinlenerek kesitleri alındı. Özofagus kesitleri Hematoksilen Eosin (HE) ile boyanarak incelendi. Her bir grup için submukoza kollajen artışı, muskularis mukoza hasarı ve tunika musku- laris hasarı olmak üzere 0-2 puan verilerek değerlendirildi.

\section{İstatistiksel Analiz}

Özofagusun histopatolojik değerlendirilmesi, grup içi ve gruplar arası karşılaştırmada Mann-Whitney $-\mathrm{U}$ testi kullanılmıştır. $\mathrm{p}<0,0001$ değerleri anlamlı olarak değerlendirilmiştir.

\section{BULGULAR}

Grup I rat'lardan ölen olmadi. Grup II rat'lardan birisi işlem sonrası ikinci günde, diğeri ise onuncu günde öldü. Grup III' de bir rat birinci günde, Grup IV' de ise bir rat ikinci günde öldü ve abdominal özofagusununda tam tabaka nekroz geliştiği görüldü. Onuncu günde ölen rat'da ise ileri derecede darl1k geliştiği saptand1.

Histopatolojik inceleme sonucu, Grup I' de submukozal kollajen artışı, muskularis mukoza hasarı ve tunika muskularis hasarı gelişmediği görüldü. Grup II' de histopatolojik incelemede üç rat'da submukozal kollojen artışının; muskularis mukoza kalınlığının 2 katından fazla olduğu, iki rat'da muskularis mukoza kalınlığının 2 katına ulaşan artış olduğu, iki rat'da ise submukozal kollojen artışının olmadığ 1 saptand1. Alt1 rat'da muskularis mukoza hasarının olduğu, bir rat'da ise olmadığı görüldü. Üç rat' da tunika muskularisi ortadan kaldıran kollojen artış1 olduğu, dört rat'da ise tunica muskularise ilerleyen kollojen artışı olduğu saptandı. Grup III' de histopatolojik incelenmede iki rat'da submukozal kollojen artışının olmadığ muskularis mukoza kalınlığının 2 katına ulaşan artış olduğu saptandı. Muskularis mukoza hasarının sadece iki rat'da olduğu görüldü. İki rat' da tunika muskularise kadar ilerleyen kollajen artışı olduğu gözlendi. Grup IV' de üç tanesinde muskularis mukoza kalınlığında 2 kata ulaşan bir artış olduğu görülürken, bir tanesinde ise 2 katından fazla arttığ 1 saptandı. Üç tanede ise submukozal kollajen artışı saptanmadi. Beş tanede muskularis mukoza hasarı olduğu saptandı. Üç rat'da tunika muskularise ilerleyen kollajen artışı, bir rat'da tunica muskularisi ortadan kaldıran kollajen artışı olduğu görülürken üç rat'da ise tunika muskularis hasarı olmadığ 1 görüldü.

Grup II, diğer gruplarla karşılaştırıldığında istatistiksel olarak anlamlı derecede submukozal 
kollajen artışı, muskularis mukoza hasarı ve tunika muskularis hasarı önemli derecede olduğu görüldü $(\mathrm{p}<0,0001)$.

Grup III ile Grup II her üç parametre açısından karşılaştırıldığında Grup III' de lezyonların daha az geliştiği ve bu farkın istatistiksel olarak anlamlı olduğu saptand1 $(p<0,0001)$.

Grup IV, Grup II ile karşılaştırıldığında; muskularis mukoza artışı ve tunika muskularis hasarı istatistiksel olarak Grup IV' den daha fazla olduğu $(\mathrm{p}<0,0001)$, muskularis mukoza hasarı açısından her iki grup arasında fark bulunmadığ 1 tespit edildi $(\mathrm{p}>0,05)$.

Grup III ile Grup IV arasinda submukozal kollajen artış yönünden anlamlı fark olduğu, Grup III' de kollajen artışının daha az geliştiği saptandı. Muskularis mukoza artışı ve tunika muskularis artış1 yönünden her iki grup arasında fark saptanmadı $(\mathrm{p}>0,05, \mathrm{p}>0,05)$.

Submukozal kollajen artışının Grup I' de \%1, Grup II' de \%43, Grup III ve IV' de ise bu oranın aynı olduğu görülmektedir. Muskularis mukoza hasarının Grup I' de oluşmadığı, Grup II' de hasarın en fazla olduğu, Grup II' de ise Grup IV' e göre daha az geliştiği görülmektedir.

Tunika muskularis hasarının deksametazon tedavisi alan Grup III' de prednizolon tedavisi alan Grup IV' e oranla daha az geliştiği görülmektedir. Tunika muskularis hasarı en fazla Grup II' de gelişmiştir. Grup III' de hasar oranı \%15 iken Grup IV' de ise bu oran \%38'dir.

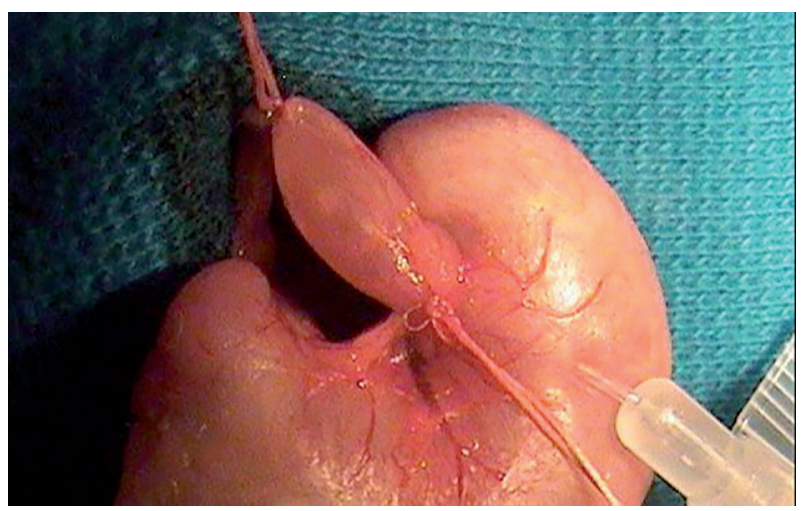

Resim 1. Abdominal özofagus proksimal ve distalinden $3 / 0$ poliglaktin sütürle asılması ve deney solüsyonunun distal özofagus içine verilmesi.

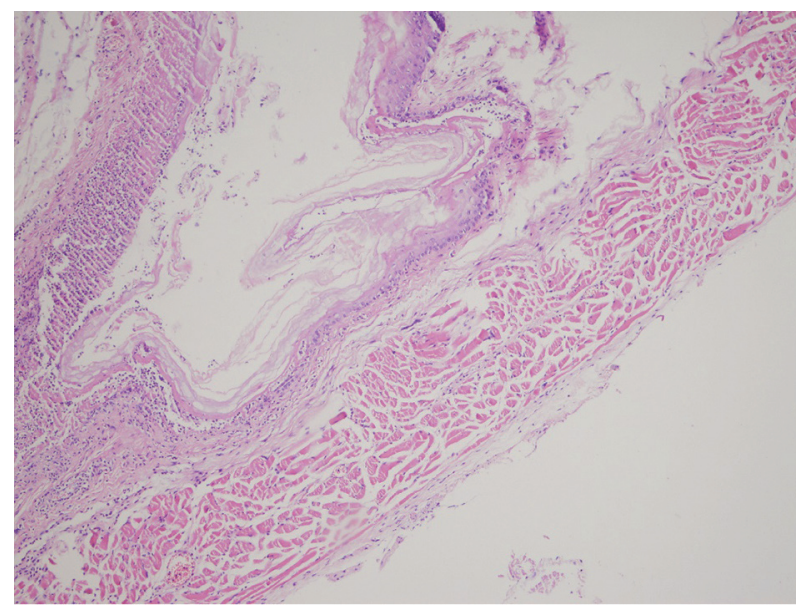

Resim 2. Grup II rat'ların özofagusunda kollajen artışı ve mukozal hasar görünümü (HE X 200)

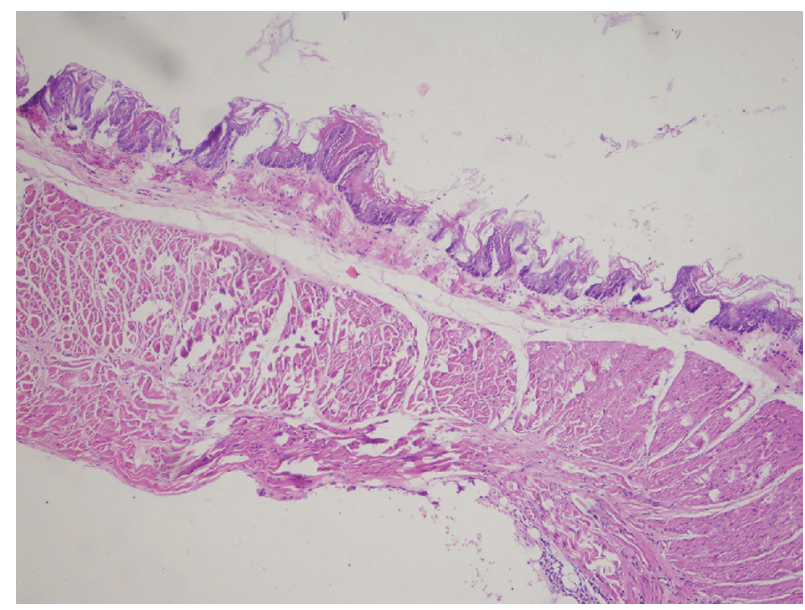

Resim 3. Grup III rat'ların özofagusunda (normale yakın) histolojik görünüm. Mukozal hasar ve kollajen oluşumunda azalma görünümü (HE X 200)

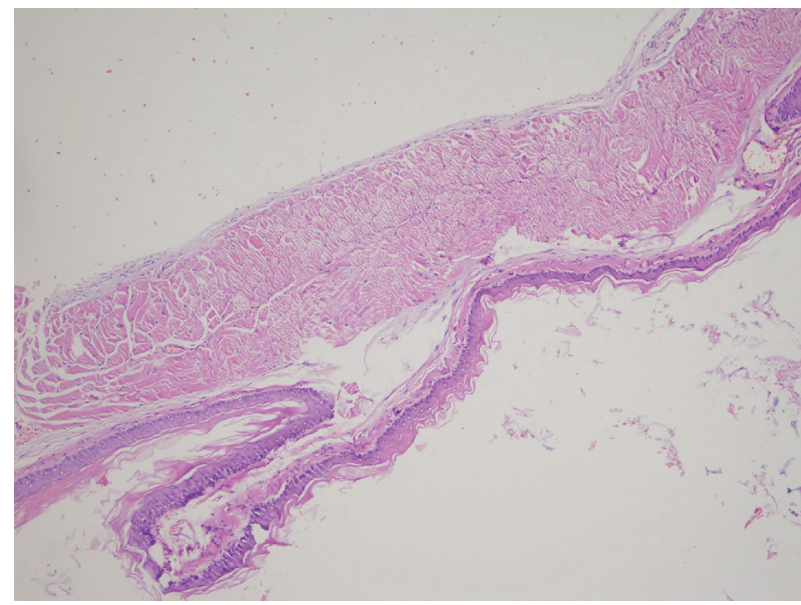


Tablo 1. Histopatolojik değerlendirme

\begin{tabular}{lc}
\hline Değerlendirme parametreleri & Skorlar \\
\hline $\begin{array}{l}\text { Submukozal kollajen artışı } \\
\text { Yok }\end{array}$ & 0 \\
Muskularis mukoza kalınlığının & 1 \\
2 katına ulaşan artış & \\
$\quad$ Muskularis mukoza kalınlığının & 2 \\
2 katından fazla artış & \\
Muskularis mukoza hasarı & \\
$\quad$ Yok & 0 \\
$\quad$ Var & 1 \\
Tunica muskularis hasarı & \\
$\quad \begin{array}{l}\text { Yok } \\
\text { Tunica muskularise ilerleyen } \\
\text { kollajen artışı }\end{array}$ & 0 \\
$\quad \begin{array}{l}\text { Tunica muskularisi ortadan kaldıran } \\
\text { kollajen artışı }\end{array}$ & 1 \\
\hline
\end{tabular}

Resim 4. Grup IV deneklerin özofagus hasarındaki hafif azalmanın histopatolojik görünümü (HE X 200)

\section{GRUPLAR ARAS SUBMUKOZA KOLLEJEI ARTTS MIKTAR GRAFIĞj}

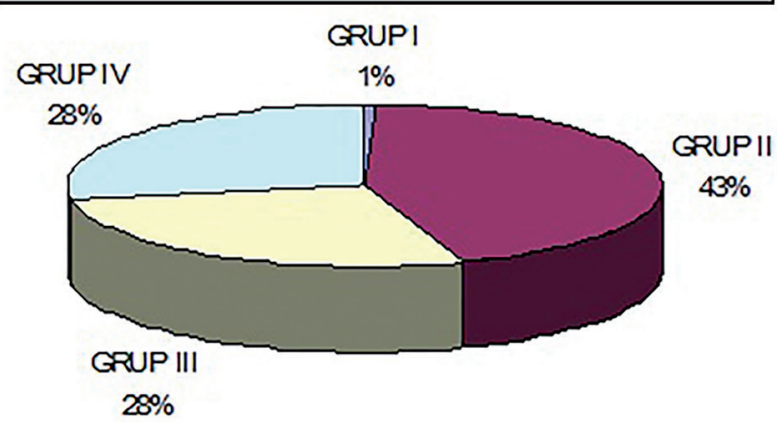

Grafik 1. Gruplardaki muskularis mukoza hasarının yüzdelik dilimi
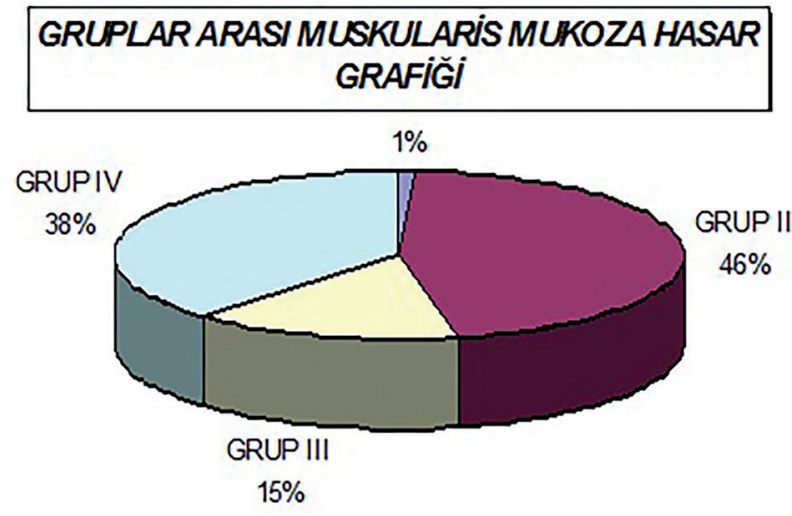

Grafik 2. Gruplardaki tunika muskularis hasarının yüzdelik dilimi

\section{TARTIŞMA}

Korozif özofagus yanıkları \% 75-90 oranında potasyum hidroksit ve sodyum hipoklorit gibi kuvvetli alkalilerin oral alımı ile gerçekleşmektedir. Özellikle 5 yaş altı çocukların yanlışlıkla ve daha büyüklerin suisid amaçlı alımı sonucu oluşur. Ülkemizdeki geniş bir korozif özofajit serisinde, özellikle Ege bölgesinde görülen KÖY'lerin \%94'ünün sodyum hidroksite bağlı geliştiği bildirilmiştir. Çalışmamız Gehanno'nun [9] tarif ettiği metoda uygun şekilde sodyum hidroksit kullanılarak KÖY oluşturarak gerçekleştirilmiştir.

Korozif maddenin oral yolla alımının ardından, özofagusta mukozal hiperemi ve ödemden, trakeoözofageal veya aortoenterik fistüllere neden olabilen derin ülserasyon ve nekroz meydana gelebilir. KÖY'de olguların \%25-50'sinde ortaya çıkan striktüre bağlı darlık meydana gelmektedir [7].

Korozif özofajitlerde asıl tedavi striktür oluşumunun önlenmesidir. KÖY sonrası yara iyileşme sürecini doğrudan etkileyen ve striktür oluşumunu önlemeye yönelik birçok farmakolojik tedavi yöntemleri tanımlanmıştır. N-asetilsistein, pensilamin, heparin, kolşisin, östradiol, hidroksiprogestron, metilprednisolon, E vitamini, ozon terapisi, interferon gama ve indometazinin bu amaçla kullanılan ajanlardır. İnflamasyon ve tromboz oluşumunu azalttıkları, kollojen sentezini önleyerek striktür oluşumunu azalttıkları deneysel çalışmalarla gösterilmiştir $[9,10]$.

Sodyum hipoklorit ile özofagus yanı̆̆1 oluşturulmuş tavşanlarda, penisilin ve kortikosteroid kullanarak striktür oluşumu ve infeksiyonları azaldığ gösterilmiştir. Fakat kortikosteroidlerin sıvı retansiyonu ve hipertansiyon yapıc1 yan etkileri bildirilmiştir [11].

$\mathrm{N}$ - asetilsistein ve pensilamin gibi ilaçların striktürü azaltmada steroidlere daha üstün olduğu gösterilmiştir. $\mathrm{N}$-asetilsistein aşırı bronşiyal sekresyona sebep olurken, pensilamin ise bakır bağlayıcı etkisi ile serum bakır düzeyi düşüklüğüne ve lökopeniye sebep olmaktadır [12].

KÖY tedavisinin temelini antibiyotik ve antienflamatuar birlikteliği oluşturmaktadır. Bu tedavinin amacı, yanığa karşı oluşan inflamasyonu kontrol altına alarak striktür oluşumunu önlemektir. $\mathrm{Bu}$ 
tedavi günümüzde yaygın olarak kullanılmaktadır $[1,2,13]$.

Özofagus yanığını takip eden dönemde striktür sıklığını bildiren çalışmalarda farklı sonuçlar bildirilmiştir. Anderson ve ark. özofagus yanığ 1 tespit edilen 60 çocuk hastanın, 31 'i 3 hafta boyunca $2 \mathrm{mg}$ / $\mathrm{kg} /$ gün prednizolon ile tedavi edilmiş. $\mathrm{Bu}$ grupta striktür gelişimi \%32,3, kontrol grubunda \%37,9 olarak saptanmıştır [14]. Çalışmamızda prednizolon ile tedavi edilen Grup IV' de muskularis mukoza artışının \%38, submukozal kollojen artışının \%28 olduğu tespit edildi. Grup I' de ise muskularis mukoza hasarı ve tunika muskularis hasarı ise $\% 46$, submukozal kollojen artışının \%43 olduğu tespit edildi.

Bir başka çalışmada 124 hastadan, özofagus yanığını takip eden 48 saat içinde steroid tedavisi alan 60 hastanın 24 'ünde (\%40) striktür geliştiğini, buna karşın 48 saatten sonra streoid tedavisi alan 64 çocuk hastanın 57'sinde (\%89) striktür geliştiğini bildirmişlerdir [15]. Yaptığımız deneysel çalışmada Grup II' deki rat'larda tunika muskularisi ortadan kaldıran kollojen artışının \%46 ile en fazla bu grupta olduğunu gördük. Grup III' teki rat'larda ise kollajen artışının daha az olduğunu, fakat muskularis mukoza ve tunika muskularis artışı yönünden her iki grup arasında anlamlı fark olmadığı saptanmıştır.

Bautista ve ark. 2. ve 3. dereceden yanıklı 36 hastayı içeren çalışmalarında prednizolon tedavisi alan 18 hastanın 12'sinde (\%66), deksametazon tedavisi alan 18 hastanın 7(\%38,9) striktür geliştiğini bildirmişlerdir. Aynı çalışmada ileri derecede striktür gelişen ve özofagus lümeni \%50'den daha fazla daralan hasta sayıs1 prednizolon grubunda $10(\% 55)$, deksametazon grubunda ise $5(\% 27,8)$ olarak saptanmıştır [16]. Her iki grubun karşılaştırılmasında ise istatistiksel olarak belirgin fark saptanmamıştır. Buna karşın tedaviden 21 gün sonra yapılan endoskopide yara iyileşmesinin deksametazon grubunda daha iyi olduğu gözlenmiştir. Yaptığımız deneysel çalışmanın sonucunda Grup IV' de ise \%28 submukozal kollojen artış1, \%38 muskularis mukoza ve tunika muskularis hasarının olduğu saptanmıştır.

Bir çalışmada tavşanlarda sodyum hidroksit kullanılarak KÖY oluşturulmuştur. Tavşanlar; kontrol grubu, prednizolon ve deksametozon grubu olmak üzere üç gruba ayrılarak histopatolojik inceleme yapılmıştır. Üçüncü derece yanık kontrol gru- bunda $\% 70$, prednizolon grubunda $\% 40$, deksametazon grubunda ise \%20 oranında görülmüştür [17]. Bizim çalışmamızda ise submukoza kollojen artışı Grup I' de \%1, Grup II' de \%43, Grup III' de \%38 Grup IV' de ise \%28 oranında saptanmıştır. Muskularis mukoza hasarı Grup I' de \%1, Grup II' de \%46, Grup III' de \%15, Grup IV' de \%38 olduğu sonucuna vardik. Tunika muskularis hasarının ise Grup I' de \%1, Grup II' de \%46, Grup III' de \%15, Grup IV' de ise $\% 38$ tespit edilmiştir.

KÖY 'de tedavinin etkin olabilmesi için erken tanı oldukça önemlidir. Rafeey ve ark. 2-12 yaşları arasında değişen, 51 KÖY hastasını (8'i asit, 43'ü alkali yanığı) değerlendirmişler. Endoskopik incelemede $\% 38$ oranında grade I , \%62 oranında ise grade II ve üstü olarak değerlendirilmiştir. Hastaların 5'inde özofagus striktürü gelişmiş olup, bu hastaların birinde mide çıkış obstrüksiyonu gelişmiştir. Erken endoskopinin bu tip hastalarda güvenilir ve prognozu belirlemede yardımcı olduğu sonucuna varılmıştır [18].

Bir başka çalışmada özofagusun $\mathrm{NaOH}$ $(\% 10, \% 5$ ve $\% 2,5), \mathrm{KOH}(\% 10, \% 5$ ve $\% 2,5)$, NaOCL $(\% 5,25)$ ve HCL $(\% 10, \mathrm{pH}: 2)$ maruziyetine intravital videomikroskopik ve histopatolojik yanıtı değerlendirilmiştir. Değerlendirmenin sonucunda $\mathrm{NaOH}$ ve KOH konsantrasyonu arttıça arteriyol ve venüllerde eliptik hızlı stazın arttığ1, arteriyoler konstriksiyon ve trombozun daha fazla olduğu görülmüştür. Sonuçta özofagus mukozasında akut korozif hasarda iskemi ve trombozun en önemli hasar olduğu, inflamasyonun ise daha az önemli olduğu ortaya çıkmıştır [19].

Sonuç olarak, alkali maddeler özofagusta KÖY oluşturarak özofagus striktürüne neden olabilirler. Medikal ve cerrahi tedavi edilen KÖY'de erken müdahale ile yüz güldürücü sonuçlar alınmaktadır. Birçok medikal tedavi protokülü bulunan KÖY için yaptığımız deneysel çalışmada, steroid tedavisinin de deksametazon ve prednizolonun tedavide etkin olduğunu saptanmıştır. Striktür gelişiminde rol oynayan kollojenizasyonun ise deksametazonda daha az olduğunu görülmüştür.

$\mathrm{Bu}$ çalışma Lokal Etik Kurul onayı alınmasını takiben, Fırat Üniversitesi Bilimsel Araştırma Projeleri (FÜBAP) tarafindan desteklenerek gerçekleştirildi. 
Çalışmamız 16. yıllık Türk Toraks Derneği Kongresi (03-07 Nisan 2013) Antalya' da sunulmuştur.

\section{KAYNAKLAR}

1. Koltuksuz U, Mutus HM, Kutlu R, et al. Effects of caffeic acid phenethyl ester and epidermal growth factor on the development of caustic esophageal stricture in rats. J Pediatr Surg 2001; 36:1504-1509.

2. Ocakcı A, Kanter M, Cabuk M, Büyükbas S. Role of caffeic acid phenenthyl ester, an active component of propolis, against $\mathrm{NAOH}$ - induced esophageal burns in rats. Int J Pediatr Otorhinolaryngol 2006; 70:1731-1739.

3. Adam JS, Brick HG. Pediatric caustic ingestion. Ann Otorhinolaryngol 1982; 91:656-658.

4. Günel E, Cağlayan O, Canbilen A, Tosun M: Effect of antioxidant theraphy on collagen synthesis in corrosive esophageal burns. Pediatr Surg Int 2002; 18:24-27.

5. Berthet B, Costanzo J, Arnaud C, et al. Influence of epidermal growth factor and interferon gamma on healing of esophageal burns in the rat. British J Surg 1994; 81:395-398.

6. Ashcraft KW, Padula RT. The effect of dilute corrosives on esophagus. Pediatrics 1974; 53:226-232.

7. Kasap E, Ozütemiz A. Pet şişedeki tehlike. Korozif özefajit. Güncel Gastroenteroloji 2006; 10:29-35.

8. Kayaalp O. T1bbi Farmakoloji. Kortikosteroidler, Kortikosteroid Antagonistleri ve ACTH. 12. Bask1, Ankara: Pelikan yayınlar1 2009:1079-1107.

9. Gehanno P, Guedon C. Inhibition of experimental esophageal lye strictures by pensilamin. Arch Otolaryngol 1981; 107:145-147.
10. Güven A, Gündogdu G, Sadir S, et al. The efficacy of ozone therapy in experimental caustic esophageal burn. J Pediatr Surg 2008; 43:1679-1684.

11. Naharcı I, Tüzün A. Kostik özefagus yaralanmaları. Güncel Gastroenteroloji 2005; 9:226-233.

12. Greiner C, Wolfer J, Hulsmann S, et al. Bioelectrical behavior of hipoxic human neocortical tissue under the influence of nimodipine and dimethyl sulfoxide. Brain Research 2003; 959:199-205.

13. Güven A, Demirbağ S, Uysal B, et al. Effect of 3- amino benzamide, a poly (adenosine diphosphate- ribose) polymerase inhibitor, in experimental caustic esophageal burn. J Pediatr Surg 2008; 43:1474-1479.

14. Anderson KD, Rouse TM, Randalph JG. A controlled trial of corticosteroids in children with corrosive injury of the esophagus. N Engl J Med 1990; 323:637-640.

15. Keskin E, Okur H, Koltuksuz Y. Effect of steroid treatment on corrosive esophageal burns in children. Eur J Pediatr Surg 1991; 1:335-338.

16. BautistaA, Tojo R, Varela R. Effects of prednisolone and dexamethasone on alkali burns of the esophagus in children. Eur J Pediatr Surg 1996; 6:198-203.

17. Baurista A, Tojo R, Varela R, et al. Effects of prednisolone and dexamethasone on alkali burns of the esophagus in rabbit. J Pediatr Gastroenterol Nutrition 1996; 22:275-283.

18. Rafeey M, Shoaran M. Clinical characteristics in oral caustic nngestion in children. Pakistan Journal of Biological Sciences 2008; 11:2351-2355.

19. Osman M, Russel J, Shukla D, et al. Responses of the murine esophageal microcirculation to acute exposure to alkali, acid, or hypochlorite. J Pediatr Surg 2008; 43:16721678 . 